\title{
Histaminergic system in brain disorders: lessons from the translational approach and future perspectives
}

\author{
Diego Baronio ${ }^{1,2,3^{*}}$, Taylor Gonchoroski ${ }^{1,3}$, Kamila Castro ${ }^{1,2,3}$, Geancarlo Zanatta ${ }^{1,3}$, Carmem Gottfried ${ }^{1,3}$ \\ and Rudimar Riesgo 1,2,3,4
}

\begin{abstract}
Histamine and its receptors were first described as part of immune and gastrointestinal systems, but their presence in the central nervous system and importance in behavior are gaining more attention. The histaminergic system modulates different processes including wakefulness, feeding, and learning and memory consolidation. Histamine receptors ( $\mathrm{H} 1 \mathrm{R}, \mathrm{H} 2 \mathrm{R}, \mathrm{H} 3 \mathrm{R}$, and $\mathrm{H} 4 \mathrm{R})$ belong to the rhodopsin-like family of $\mathrm{G}$ protein-coupled receptors, present constitutive activity, and are subjected to inverse agonist action. The involvement of the histaminergic system in brain disorders, such as Alzheimer's disease, schizophrenia, sleep disorders, drug dependence, and Parkinson's disease, is largely studied. Data obtained from preclinical studies point antagonists of histamine receptors as promising alternatives to treat brain disorders. Thus, clinical trials are currently ongoing to assess the effects of these drugs on humans. This review summarizes the role of histaminergic system in brain disorders, as well as the effects of different histamine antagonists on animal models and humans.
\end{abstract}

Keywords: Antagonist, Autism, Brain disorders, Histamine, Histaminergic system

\section{Introduction}

Described for the first time in 1910 as a promoter of contraction of smooth muscles and vasodilatation, histamine acts as a transmitter in the central nervous system (CNS) and modulates several other physiological processes, like gastrointestinal and circulatory functions, innate and acquired immunity, cell proliferation and hematopoiesis. Today, its presence in the CNS and importance in behavior are largely studied $[1,2]$.

Histamine synthesis and release are regulated by H3R, an autoreceptor present in the somata and axon terminals of histaminergic neurons. Histamine is synthesized from L-histidine by histidine decarboxylase, and it is metabolized by diamine oxidase and histamine $N$-methyltransferase (HNMT) [3]. Other receptors, such as muscarinic,

\footnotetext{
* Correspondence: diego@baronio.com.br

${ }^{1}$ Translational Research Group in Autism Spectrum Disorders (GETTEA), Ramiro Barcelos, 2350 - Santa Cecília, Porto Alegre RS 90035-903, Brazil ${ }^{2}$ Postgraduate Program in Child and Adolescent Health, Federal University of Rio Grande do Sul, Porto Alegre, RS, Brazil

Full list of author information is available at the end of the article
}

opioid, and galanin, regulate histamine release in specific brain regions [4-6].

Histaminergic neurons are located in the tuberomamillary nucleus (TMN) of the hypothalamus, with widespread projections innervating most brain areas. Postmortem studies indicate that the number of histaminergic neurons in humans is about 64,000 [7]. There are four histamine receptors, all part of the rhodopsin-like family of G protein-coupled receptors (GPCR). Through these receptors, histamine regulates several basic body functions, such as wakefulness, feeding, and learning and memory [8-10].

\section{Histamine receptors}

In 1966, Ash and Schild discovered the H1R while studying the effect of antihistamine drugs in the rat uterus and stomach [11]. After that, three other receptors (H2R, H3R, and H4R) were identified. The four receptors are part of the GPCR superfamily, and they all present constitutive activity [12-15].

The GPCR superfamily modulates several physiological processes and is divided into families and subfamilies, and single subtypes can present different isoforms. The 
discovery of constitutively active mutant receptors proved that these receptors could be activated without the presence of an agonist [16]. Binding of a ligand to a receptor may initiate activity (agonist with positive intrinsic activity) or prevent the effect of an agonist (antagonist with zero intrinsic activity). While the agonists stabilize the receptor in active conformation, the inverse agonists stabilize the receptor in inactive conformation and thus reduce the activity (negative intrinsic activity) [17]. Two isoforms of the H3R are highly constitutively active: the wild type and an isoform with a deletion in the third intracellular loop [18].

From the four histaminergic receptors, H1R is the main target of most of the approved drugs [19] and is found in different tissues and cells, including the smooth muscle, brain, and lymphocytes [20,21]. This receptor is the only member of the family of histamine receptors, of which a co-crystal was obtained, by using the firstgeneration antagonist doxepin (PDB ID 3RZE) [22]. As for all members of this family, this receptor comprises seven transmembrane helices (TMH), three intracellular loops, and three extracellular loops. The binding pocket of $\mathrm{H} 1 \mathrm{R}$ has a conserved hydrophobic nature, which contributes to the low selectivity of doxepin and the first-generation of H1R antagonists, and is associated to an anion-binding region which has been related to the binding of second-generation H1R antagonists. Such crystallographic structure can be used as a model in further development of new blockers as well as in the understanding of the activation-inactivation mechanisms of this receptor family at molecular level. The signal transduction of H1R includes activation of phospholipase $\mathrm{C}$, which promotes the inositol triphosphate-dependent release of $\mathrm{Ca}^{2+}$ from intracellular stores and diacylglycerol-sensitive activation of protein kinase $C[2,23]$.

$\mathrm{H} 1 \mathrm{R}$ is involved in the modulation of important processes and mice lacking this receptor present different impairments, for example, in spatial memory and in sleepwake characteristics $[24,25]$. Injection of a H1R agonist in the median preoptic nucleus, a region involved in basal thermoregulation, induces persistent hyperthermia [26]. Other study with mutant mice lacking H1R suggested a role for this receptor in somatic and visceral pain perceptions. These animals showed fewer nociceptive responses to the hot-plate, tail-flick, tail-pressure, paw-withdrawal, formalin, capsaicin, and abdominal constriction tests [27].

The pioneer study by Ash and Schild indicated, at that time, the existence of at least two classes of histamine receptors, since the antagonists utilized in that experiment did not stop gastric acid secretion [11]. Later, compounds that blocked the gastric acid secretion in guinea pig, named $\mathrm{H} 2 \mathrm{R}$ antagonists, were developed by Black and colleagues [28]. Like H1R, H2R presents typical GPCR receptor characteristics. Its activation stimulates adenylyl cyclase leading to cyclic adenosine monophosphate (cAMP) production, a second messenger that has different roles in the cell [29]. The role of H2R in the CNS is not fully understood, but basic research showed that it is related to the processes of learning and memory, motor control, and thermoregulation [30,31]. In some areas of the brain, colocalization of H1R and H2R suggests synergistic interactions between these two receptors [32]. In an animal model of multiple sclerosis, it was demonstrated that both H1R and H2R are propathogenic, mediating immune deviation and blood brain barrier (BBB) disruption [33].

Mainly found in the brain, H3R regulates food intake, memory, acetylcholine (ACh) release, and consolidation of fear memories [34,35]. Activation of H3R inhibits cAMP synthesis and activates MAP kinases and the AKT/GSK3 $\beta$ axis [36-38]. When activated, the receptor inhibits cell firing and decreases the release of histamine by histaminergic neurons, as well as inhibits secretion of norepinephrine, serotonin, and other neurotransmitters [13,39,40]. Recently, several alterations were reported in mice lacking H3R. They presented enhanced histaminergic neurotransmission, which led to changes in the mice phenotype, indicating a possible metabolic disorder as a consequence. The sleep was also altered, in a condition similar to sleep restriction in humans, which matches with obesity tendency presented by these animals [41].

Almost 15 years ago, H4R was the last histamine receptor to be identified. It is mainly related with immune functions, but its presence in the brain is known, as well as in the bone marrow, peripheral blood, spleen, thymus, small intestine, colon, heart, and lung [42-44]. It modulates different processes such as dendritic cells activity, interleukins release, and likely regulation of BBB permeability [45-47].

In humans, the presence of H4R messenger RNA (mRNA) was detected in the spinal cord, hippocampus, cerebral cortex, thalamus, and amygdala, with levels in the spinal cord overcoming the levels found in the spleen and liver. The authors also verified the presence of the receptor in the dorsal root ganglia, which might indicate a nociceptive role for the receptor. In rats, the cerebellum and hypothalamus presented the highest amounts of H4R mRNA [48].

\section{Histaminergic system and brain disorders}

Alterations in the histaminergic system have been reported in several brain disorders and might have a significant role in their pathophysiology [49-52]. Considering this, it is not surprising that pharmacological studies are in development to explore the potentialities of histamine antagonists/inverse agonists in the treatment of these disorders. Table 1 shows the uses and outcomes of histamine receptors antagonists cited in this review. 
Table 1 Histamine receptors antagonists: therapeutic applications and outcomes

\begin{tabular}{|c|c|c|c|c|c|}
\hline Receptor & Drug & Disorder & Study & Outcome & Reference \\
\hline \multirow[t]{3}{*}{$\mathrm{H} 1 \mathrm{R}$} & Chlorpheniramine & $\begin{array}{l}\text { Model of stress by immobilization/sleep } \\
\text { disturb }\end{array}$ & Preclinical & Reduction in REM sleep. & [53] \\
\hline & Dimebon & $A D$ & Clinical & No significant improvement in a phase III trial. & [54] \\
\hline & Doxepin & Insomnia & Clinical & $\begin{array}{l}\text { Improvements in sleep maintenance and duration } \\
\text { in a 4-week outpatient trial of elderly adults. }\end{array}$ & {$[55,56]$} \\
\hline \multirow[t]{3}{*}{$\mathrm{H} 2 \mathrm{R}$} & Dimebon & $A D$ & Clinical & No significant improvement in a phase III trial. & [54] \\
\hline & Famotidine & Autism & Clinical & $\begin{array}{l}\text { Attenuated symptoms like irritability, hyperactivity } \\
\text { and atypical pattern of eye contact in children } \\
\text { with autism. }\end{array}$ & {$[57]$} \\
\hline & & $\mathrm{SCH}$ & Clinical & Reduced scores in BPRS, CGI, and SANS. & {$[58,59]$} \\
\hline \multirow[t]{17}{*}{$\mathrm{H} 3 \mathrm{R}$} & GSK239512 & $A D$ & Clinical & $\begin{array}{l}\text { Failed on improving executive function/working } \\
\text { memory in a randomized, double-blind, } \\
\text { placebo-controlled. }\end{array}$ & {$[60]$} \\
\hline & ABT-288 & $A D$ & Clinical & No significant improvements in a randomized study. & [61] \\
\hline & & $\mathrm{SCH}$ & Clinical & $\begin{array}{l}\text { Failed on providing cognitive improvements } \\
\text { to patients. }\end{array}$ & {$[62]$} \\
\hline & JNJ-10181457 & Model of AD & Preclinical & $\begin{array}{l}\text { Reversed cognitive deficits induced by scopolamine } \\
\text { and normalized ACh neurotransmission. }\end{array}$ & {$[63]$} \\
\hline & Pitolisant & Narcolepsy & Clinical & Reduced excessive daytime sleepiness & [64] \\
\hline & ABT-239 & Model of $\mathrm{SCH}$ & Preclinical & $\begin{array}{l}\text { Attenuated cognitive deficits caused by ketamine } \\
\text { and MK- } 801 \text {. }\end{array}$ & {$[50]$} \\
\hline & A-431404 & Model of SCH & Preclinical & $\begin{array}{l}\text { Attenuated cognitive deficits caused by ketamine } \\
\text { and MK-801. }\end{array}$ & {$[50]$} \\
\hline & JNJ-31001074 & $\mathrm{ADHD}$ & Clinical & No significant improvements in adult patients. & {$[65]$} \\
\hline & Betahistine & $\mathrm{SCH}$ & Clinical & $\begin{array}{l}\text { Reduced weight gain by patients with } \mathrm{SCH} \\
\text { treated with olanzapine. }\end{array}$ & {$[66]$} \\
\hline & JNJ-39220675 & Model of alcoholism & Preclinical & $\begin{array}{l}\text { Reduced intake of alcohol after a period of } \\
\text { abstinence. }\end{array}$ & {$[67]$} \\
\hline & Thioperamide & Model of $\mathrm{SCH}$ & Preclinical & Enhancement of prepulse inhibition. & [68] \\
\hline & & Model of PD & Preclinical & Decreased hyperactivity. & [69] \\
\hline & GSK189254 & Model of neuropathic pain & Preclinical & Antinociceptive effect. & {$[70,71]$} \\
\hline & GSK334429 & Model of neuropathic pain & Preclinical & Antinociceptive effect. & [71] \\
\hline & SAR1 10894 & Model of SCH & Preclinical & Normalized impaired social behavior. & [72] \\
\hline & Ciproxifan & Model of SCH & Preclinical & Enhancement of prepulse inhibition. & [68] \\
\hline & & Model of AD & Preclinical & Improvements in hyperactivity and memory deficits. & {$[73]$} \\
\hline \multirow[t]{6}{*}{ H4R } & JNJ7777120 & Model of neuropathic pain & Preclinical & Antinociceptive effect. & {$[74,75]$} \\
\hline & ZPL3893787 & $\begin{array}{l}\text { Tested in healthy volunteers. Potential } \\
\text { treatment for asthma, allergic rhinitis, } \\
\text { pain, and other inflammatory diseases. }\end{array}$ & Clinical & Completed phase I trial. Safe and well tolerated. & {$[76]$} \\
\hline & UR63325 & Allergic rhinitis & Clinical & Currently on phase II clinical trial. No data available. & [76] \\
\hline & KD1157 & $\begin{array}{l}\text { Tested in healthy volunteers. Potential } \\
\text { treatment for allergic rhinitis. }\end{array}$ & Clinical & Safe and well tolerated. & [76] \\
\hline & JNJ38518168 & Asthma & Clinical & Currently on phase II clinical trial. No data available. & [76] \\
\hline & JNJ39758979 & Asthma & Clinical & Completed phase II clinical trial. No data available. & [76] \\
\hline
\end{tabular}

\section{Alzheimer's disease}

Alzheimer's disease (AD) affects approximately 5.4 million US citizens and the costs with patients, including health care, long-term care, and hospitalization, make it a social problem [77]. Even though there is conflicting information about the role of histaminergic system in $\mathrm{AD}$, abnormalities have been reported. A postmortem study showed reduced histamine content in the hypothalamus, hippocampus, and temporal cortex of patients with $\mathrm{AD}$ [7]. Other report showed 57\% less histaminergic 
neurons in the TMN of AD patients and females had increased prefrontal cortex expression of H3R. Despite the severe cell loss, it is suggested that histamine production is not affected, since the levels of histidine decarboxylase mRNA are unaltered [78]. On the other hand, Kim and colleagues reported decreased levels of the histamine-releasing factor in the temporal cortex of patients with $\mathrm{AD}$, as well as in the temporal cortex, thalamus, and caudate nucleus of patients with Down syndrome, indicating low levels of brain histamine in these disorders [79].

The development of new treatments for AD is a permanent issue. Positive results after a double-blind, placebocontrolled, phase II trial led to great expectations about the possibility of dimebon becoming a drug to treat $\mathrm{AD}$, with patients displaying significant improvement over baseline for Alzheimer's disease Assessment Scale [80]. Dimebon acts as an antagonist of $\mathrm{H} 1 \mathrm{R}$ and $\mathrm{H} 2 \mathrm{R}$, and it also binds to adrenergic, serotonergic, and dopaminergic receptors. Unfortunately, a phase III trial with 598 patients found no significant improvement in patients with $\mathrm{AD}$ treated with this drug [54].

In a preliminary investigation GSK239512, an H3R antagonist/inverse agonist was tested in order to assess its tolerability and cognitive effects in patients with AD. The patients displayed no abnormalities in hematology, clinical chemistry, urinalysis parameters, and cardiovascular parameters. Enhancements in cognition were assessed, with subjects showing positive effects on attention and memory [60]. In a larger trial, GSK239512 was considered safe and able to improve episodic memory in patients with $\mathrm{AD}$, but it failed on improving executive function/working memory [81]. Other H3R antagonists, such as ABT-288, have also failed in clinical trials [61].

On the other hand, interesting findings were reported when ciproxifan, also H3R antagonist, was tested in a transgenic mouse model of AD. Improvements in some impairments featured in this disorder, such as hyperactivity and memory deficits were detected after administration of this drug [73]. This was also performed with rats that received scopolamine, a non-selective muscarinic antagonist that induces cognitive impairments and reduces ACh release, similar to what is found in AD. Treatment with JNJ-10181457, a selective non-imidazole H3R antagonist, not only reversed cognitive deficits induced by scopolamine but also normalized ACh neurotransmission [63].

\section{Sleep disturbs}

Histamine has an important role in the control of sleepwake regulation. Studying histaminergic TMN neurons of cats in different states, Vanni-Mercier reported a slow, but regular spontaneous firing during wake state, diminished in slow-wave sleep and absent firing during rapid eye movement [82]. Histidine decarboxylase gene knockout mice showed that impaired histamine synthesis prevents remaining in a wake state [83]. In agreement with that, patients with narcolepsy and idiopathic hypersomnia present reduced level of histamine in the cerebrospinal fluid (CSF) [84].

In rats, inverse agonism of H1R with ketotifen increased non-rapid eye movement (REM) sleep and decreased REM sleep, coinciding with significant prolongation of sleep duration and longer slow-wave sleep, suggesting a restful sleep [85]. In a model of stress by immobilization, the percentage for REM sleep is increased but is abolished in rats after administration of an H1R antagonist/inverse agonist, chlorpheniramine. The reduction of REM sleep caused by chlorpheniramine administration was significant even when compared to non-stressed control rats [53].

Recently, doxepin efficacy and tolerability were tested in elderly patients with chronic primary insomnia. During 4 weeks, 130 patients received $6 \mathrm{mg}$ of doxepin nightly while 124 patients received placebo. According to patient self-report instruments and clinician ratings, the treatment was well tolerated and led to significant improvements in sleep maintenance and duration [55]. Another recent trial investigated the effects of doxepin in Parkinson's disease (PD) patients with insomnia. Non-pharmacological treatment, $10 \mathrm{mg}$ of doxepin nightly and placebo were compared during 6 weeks. Sleep variables were improved in the doxepin-treated and in the non-pharmacological groups, with the doxepin treatment appearing to have more substantial clinical benefits. The authors do not claim for a superiority of pharmacological treatment and point to advantages of the non-pharmacological, such as absence of pharmacological side effects and potential long-lasting benefits after treatment [56].

Beneficial effects of histamine antagonists are also seen in narcoleptic patients that received $40 \mathrm{mg}$ of tripolisant daily for a week. The H3R inverse agonist was considered safe, and no serious adverse effects were reported during the study. Despite the small population studied, the authors highlight that after treatment, patients presented a reduction in somnolence, compared to baseline, equivalent to results after several months of modafinil treatment [64]. The same drug was tested in four teenagers with narcolepsy-catalepsy that presented severe daytime sleepiness and were refractory to available treatments. Pitolisant decreased sleepiness with few minor adverse effects [86]. In positron emission tomography (PET) study, after calculating H3R occupancy, it was verified that AZD5213 is able to exert its wake-promoting action during daytime and does not disrupt sleep during the night. This is consequence of its pharmacokinetics that allows circadian fluctuations of H3R occupancy. Thus, patients would benefit from the procognitive effects of H3R without presenting sleep disruption [87]. 


\section{Schizophrenia}

Schizophrenia $(\mathrm{SCH})$ is a heterogeneous disorder with strong genetic influence, highly prevalent, affecting $1.1 \%$ of the US population [88]. The involvement of the dopaminergic system in the pathophysiology of this disorder is well known, with antipsychotics acting mainly on $\mathrm{D}_{2}$ receptor [89]. However, a role for the histaminergic system has been proposed, and several novel pharmaceutical targets are acting on both dopaminergic and histaminergic systems [90]. Iwabuchi and colleagues evaluated the distribution of H1R in the brains of medicated schizophrenic patients and normal human subjects but found no discrepancy between the groups. They also calculated the binding potential of the receptor by PET and doxepin, a radioligand for $\mathrm{H} 1 \mathrm{R}$, and noted that the value of the binding potential was particularly lower in the frontal and prefrontal cortices and the cingulate gyrus of patients with $\mathrm{SCH}$ [51]. Analyzing postmortem brain samples of patients with $\mathrm{SCH}$, Jin and colleagues found that medicated patients displayed lower H3R binding level in the hippocampal CA2 region. The prefrontal cortices of the same patients presented higher H3R radioligand binding than the controls', and this alteration was correlated with psychotic symptoms, indicating a role of H3R in modulation of cognition [91]. Recently, it was reported that a H4R polymorphism may be a molecular marker for the prediction of risperidone efficacy [92].

In the 1990s, the effect of an H2R antagonist, commonly used in the treatment of peptic ulcer, was evaluated in patients with SCH. During 3 weeks, in an open-label trial, ten patients received $20 \mathrm{mg}$ twice a day of famotidine without interrupting their treatment with conventional antipsychotics. Famotidine led to significant reduction in the scores of Brief Psychiatric Rating Scale (BPRS) and Clinical Global Impression (CGI), suggesting its administration as a useful alternative for $\mathrm{SCH}$ treatment [58]. Later, another open-label trial was performed with 18 patients receiving $100 \mathrm{mg}$ of famotidine daily, during 3 weeks. Significant improvements were found after measurements with BPRS, CGI, and the Schedule for the Assessment of Negative Symptoms (SANS) [93]. Recently, a randomized clinical trial for famotidine was performed with 30 patients with $\mathrm{SCH}, 16$ patients received $100 \mathrm{mg}$ of famotidine twice daily and 14 received placebo. Famotidine caused no significant adverse effects, and it led to great reduction in symptoms for both the Positive and Negative Syndrome Scale and CGI [59].

In an animal model of $\mathrm{SCH}$, impaired prepulse inhibition was enhanced in the $\mathrm{DBA} / 2$ mouse after inverse agonism of H3R with thioperamide and ciproxifan [68]. The use of ABT-239 and A-431404, also non-imidazole H3R antagonists, attenuated cognitive deficits caused by ketamine and MK-801 in rats, showing better results than antipsychotics, olanzapine, and risperidone, also used in the study, to treat these deficits [50]. Antagonists/inverse agonists of H3R have also shown to possess antioxidant activity, which could supplement antioxidant needs of $\mathrm{SCH}$ [94]. Despite the promising results obtained in preclinical models, when ABT-288 was tested in a randomized trial, it failed in providing cognitive improvements to patients with $\mathrm{SCH}$. In addition, this treatment was associated with sleep disruption [62]. Other reports of disappointing results regarding the use of H3R antagonists in the treatment of disorders, such as attention-deficit hyperactivity disorder (ADHD), raise questions about the practicability of these drugs on the translational level [65].

Weight gain is a common side effect associated with some antipsychotic agents that may affect adherence to treatment [95]. Recently, the use of H3R antagonists was investigated as an alternative to attenuate weight gain caused by olanzapine in patients with $\mathrm{SCH}$. A combination of reboxetine, a selective norepinephrine reuptake inhibitor, and betahistine, a potent antagonist of H3R was tested in a double-blind placebo-controlled study. The combination of $4 \mathrm{mg}$ of reboxetine and $48 \mathrm{mg}$ of betahistine was given daily, for 6 weeks, to 29 patients treated with olanzapine. Placebo was given to 14 patients also treated with olanzapine. The combination of reboxetine/ betahistine resulted in significantly less weight gain compared to the placebo group [66].

\section{Addiction}

It is known that alterations in different neurotransmission systems, such as glutamate system dysfunction, interaction between serotonin transporter and serotonin receptor $1 \mathrm{~B}$ genes polymorphisms, and dopamine-beta hydroxylase polymorphism have been associated with drug dependence [96-98]. The histaminergic system might as well be involved in modulation of behaviors associated with addiction. A polymorphism of HNMT gene was found in abundance in alcoholics from two different populations. Higher levels of the enzyme HNMT may lead to decreased levels of histamine and the low levels of this amine could be linked to an anxious behavior, since the patients with the polymorphism also displayed higher harm avoidance, a dimensional rating of anxious personality. Vulnerability to alcohol dependence is commonly associated with anxious behavior. In animals, it was demonstrated that stimulation of H1R modulates an anxiogenic effect, while H2R does the opposite. The authors speculate that the carriers of the polymorphism may present low levels of histamine in the amygdaloid nuclei, a structure associated with anxiety and with high density of H2R [99].

Nuutinen and colleagues showed that when alcohol solution and plain water were offered to mice lacking H3R in a two-bottle choice procedure, these animals would drink less alcohol solution, compared to control animals. Also, in animals without the H3R, alcohol did not generate 
a rewarding effect, as well as not impaired motor coordination [100]. Similar results were obtained when rats were treated with JNJ-39220675. After 3 days of deprivation, rats were exposed to alcohol again 15 min after receiving a subcutaneous injection of JNJ-39220675. The animals displayed reduced intake of alcohol after a period of abstinence, just when the urge for drinking is enhanced [67]. Clinical studies should be performed to assess potential benefits and risks of these drugs to treat alcoholic patients.

\section{Parkinson's disease}

Reports of higher levels of histamine in the blood of patients with PD and in postmortem studies indicate a role for the histaminergic system on this disease [101]. The histaminergic innervation in the middle portion of substantia nigra pars compacta and reticulata was increased in the brains of patients with PD, which may be due to a compensatory event caused by deficiency of dopamine or a putative fiber growth inhibitory factor [102]. In postmortem brain samples of patients with PD, histamine concentrations were significantly increased in the putamen, substantia nigra pars compacta, internal globus pallidus, and external globus pallidus when compared to age-matched controls. This is probably a consequence of reduced metabolism, since the concentrations of tele-methylhistamine, a histamine metabolite, were unchanged [103]. Other study reported a significant decrease in the expression of H3R mRNA and a significant increase of HNMT mRNA expression, both in the substantia nigra of patients with PD. The disease duration (years between diagnosis and death) was negatively correlated with HNMT mRNA expression [104].

In a rat model of $\mathrm{PD}$, obtained by brain lesion after bilateral icv administration of 6-hydroxydopamine, high levels of histamine were identified. Increased locomotor activity caused by the lesion and stereotyped behavior promoted by injection of apomorphine, were attenuated by administration of thioperamide, a H3R antagonist. Antagonists of H1R and H2R were also tested, but the symptoms caused by the lesion were not attenuated [69].

\section{Pain}

The histaminergic system has a role in nociception, with histaminergic neurons projecting to the dorsal raphe nucleus and dorsal horn of the spinal cord. The H3R antagonists GSK189254 and GSK334429 demonstrated to be promising therapies for the treatment of neuropathic pain, since animals treated with these drugs presented a decrease in paw withdrawal threshold in the chronic constriction injury and varicella-zoster virus models [70]. In addition, GSK189254 produced antinociceptive effects in the model of monoiodoacetate induced osteoarthritic pain and in a spinal nerve ligation model of neuropathic pain [71].

Antinociceptive properties of H4R antagonists were also detected. JNJ7777120 was tested in four different strains of mice in order to verify its efficacy in a model of croton oil-induced ear inflammation. Reduction in ear edema and significant anti-inflammatory effects were detected in the animals treated with this drug [74]. In other study, after repeated administration, JNJ7777120 demonstrated an anti-hyperalgesic action in a model of neuropathic pain. It is not clear how this effect is produced, although JNJ7777120 possesses anti-inflammatory properties, it is also possible that a central effect is produced due to its capacity to cross the BBB [75]. Clinical studies are currently ongoing in order to evaluate the therapeutic potential of H4R antagonist in other inflammatory diseases, due to the involvement of H4R in immune regulatory functions, including chemotaxis and cytokine secretion [76].

\section{Perspectives}

Over the last years, the role of histaminergic system has been studied in the pathophysiology of different brain disorders. Progress in this field of study has been made, making it possible to investigate different pharmacological approaches in order to treat or ameliorate symptoms. Autism, a neurodevelopmental disorder, affects 1 in 68 children in the US and has not a clear etiology or specific biomarkers [105]. Literature presents scarce data about the histaminergic system in autism (Table 2), but the use of an H2R antagonist has been already proposed and tested in patients. Symptoms like irritability, hyperactivity, and atypical pattern of eye contact were attenuated after treatment with famotidine $[57,106]$.

There is evidence that H3R is downregulated in Fragile $\mathrm{X}$ syndrome patients, a condition that is strongly associated with autism [111]. In addition, animals exposed to phencyclidine (PCP) develop behavioral impairments, including low interest in social novelty, which is a feature present also in autism. In this experiment, animals exposed to PCP spent 3.5 less time investigating a novel subject than the control group. The administration of a H3R antagonist/inverse agonist, SAR110894, normalized this impairment [72]. Recent data points to an involvement of the histaminergic system in the pathophysiology of Tourette's syndrome, a condition common among patients with autism. A premature termination codon (W317X) in the histidine decarboxylase gene was detected in patients, implying that diminished histaminergic neurotransmission could be related to the outcomes of this syndrome [114].

Since it is likely that the histaminergic system may play a role in $\mathrm{SCH}$ and Tourette's syndrome, disorders that have substantial symptomatic overlap with autism, 
Table 2 Studies involving autism and histamine

\begin{tabular}{|c|c|c|c|c|}
\hline Year & Author & Number of patients & Number of controls & Main results \\
\hline 1972 & Neville et al. & 7 & - & Elevated plasma histidine and low skin histidase levels [107]. \\
\hline 1979 & Kotsopoulos and Kutty & 1 & - & $\begin{array}{l}\text { Patient with autism presented histidine blood levels seven } \\
\text { times higher than the upper normal values [108]. }\end{array}$ \\
\hline 1988 & Launay et al. & 22 & 22 & $\begin{array}{l}\text { Histamine levels in urine and whole blood or plasma of patients } \\
\text { with autism did not differ from age- and sex-matched controls [109]. }\end{array}$ \\
\hline 1999 & Rossi et al. & 25 & - & $\begin{array}{l}\text { Niaprazine (H1R antagonist) showed a positive effect on hyperkinesias, } \\
\text { unstable attention, resistance to change and frustration, mild anxiety } \\
\text { signs, hetero-aggressiveness, and sleep disorders [110]. }\end{array}$ \\
\hline 2001 & Linday et al. & 9 & - & $\begin{array}{l}\text { Behavioral improvement in children treated with Famotidine } \\
\text { (H2R antagonist) [57]. }\end{array}$ \\
\hline 2010 & Rosales-Reynoso et al. & 10 & 10 & $\begin{array}{l}\text { Downregulation of } \mathrm{H} 3 \mathrm{R} \text { in patients with Fragile } X \text { syndrome, subjects } \\
\text { that usually meet diagnostic criteria for autism [111]. }\end{array}$ \\
\hline 2012 & Ming et al. & 48 & 53 & Reduced urinary levels of histidine and other amino acids [112]. \\
\hline 2013 & Naushad et al. & 138 & 138 & $\begin{array}{l}\text { When compared to normal controls, autistic children showed elevated } \\
\text { levels of histidine ( } 58+/-15 \text { vs. } 45+/-21 \text { micromol/L) [113]. }\end{array}$ \\
\hline
\end{tabular}

we think that further investigation should be made to characterize this system in autism. The animal model of autism based on prenatal exposure to valproic acid shows neuroanatomical, behavioral, and biochemical alterations that recapitulates the core characteristics of autism [115], which makes it a reliable tool for studying a likely involvement of the histaminergic system in this disorder.

\section{Concluding remarks}

Initially described as part of immune and gastrointestinal systems, the presence of histamine and its four described receptors in the CNS have been related to normal and/ or abnormal behavior. As a result, a growing amount of information regarding the relationship between histamine and brain is continuously arising from both experimental and clinical fields of research.

Based on preclinical data, different antagonists from histamine receptors have been considered promising therapies for brain disorders. On the other hand, more clinical studies are still required to verify practicability of these drugs. We believe that in-depth investigation involving the histaminergic system and its potential therapeutic targets in other disorders, such as autism, should be performed. Efforts in both preclinical and clinical research will lead to reaching clinically useful and safe treatments.

\section{Abbreviations}

H1R: histamine $\mathrm{H} 1$ receptor; H2R: histamine $\mathrm{H} 2$ receptor; H3R: histamine H3 receptor; H4R: histamine H4 receptor; CNS: central nervous system; HNMT: histamine N-methyltransferase; TMH: transmembrane helices; TMN: tuberomamillary nucleus; GPCR: G protein-coupled receptors; BBB: blood brain barrier; AD: Alzheimer's disease; SCH: schizophrenia; PD: Parkinson's disease; ACh: acetylcholine; PCP: phencyclidine; PET: positron emission tomography; BPRS: brief psychiatric rating scale; ADHD: attentiondeficit hyperactivity disorder; CGI: Clinical Global Impression.

\section{Competing interests}

The authors declare that they have no competing interests.

\section{Authors' contributions}

DB, TG, KC, and GZ wrote and edited the manuscript. CG and RR provided the conceptual input and edited the manuscript. All authors participated in the discussion and approved the final submitted version.

\section{Acknowledgements}

DB is funded by the National Council for Scientific and Technological Development (CNPq), Coordination for the Improvement of Higher Education Personnel (CAPES), and Research Incentive Fund from the Clinical Hospital of Porto Alegre (FIPE/HCPA). There is not a conflict of financial and/or other interest.

\section{Author details}

${ }^{1}$ Translational Research Group in Autism Spectrum Disorders (GETTEA), Ramiro Barcelos, 2350 - Santa Cecília, Porto Alegre RS 90035-903, Brazil. ${ }^{2}$ Postgraduate Program in Child and Adolescent Health, Federal University of Rio Grande do Sul, Porto Alegre, RS, Brazil. ${ }^{3}$ Research Group in Neuroglial Plasticity, Department of Biochemistry, Federal University of Rio Grande do Sul, Porto Alegre, RS, Brazil. ${ }^{4}$ Child Neurology Unit, Clinical Hospital of Porto Alegre, Federal University of Rio Grande do Sul, Porto Alegre, RS, Brazil.

Received: 19 March 2014 Accepted: 21 October 2014

Published online: 18 November 2014

\section{References}

1. Dale HH, Laidlaw PP: The physiological action of beta-iminazolylethylamine. J Physiol 1910, 41(5):318-344.

2. Haas HL, Sergeeva OA, Selbach O: Histamine in the nervous system. Physiol Rev 2008, 88(3):1183-1241.

3. Schwartz JC, Arrang JM, Garbarg M, Pollard H, Ruat M: Histaminergic transmission in the mammalian brain. Physiol Rev 1991, 71(1):1-51.

4. Gulat-Marnay C, Lafitte A, Arrang JM, Schwartz JC: Regulation of histamine release and synthesis in the brain by muscarinic receptors. J Neurochem 1989, 52(1):248-254.

5. Gulat-Marnay C, Lafitte A, Arrang JM, Schwartz JC: Modulation of histamine release in the rat brain by kappa-opioid receptors. J Neurochem 1990, 55(1):47-53.

6. Arrang JM, Gulat-Marnay C, Defontaine N, Schwartz JC: Regulation of histamine release in rat hypothalamus and hippocampus by presynaptic galanin receptors. Peptides 1991, 12(5):1113-1117.

7. Panula P, Airaksinen MS, Pirvola U, Kotilainen E: A histamine-containing neuronal system in human brain. Neuroscience 1990, 34(1):127-132 
8. Sundvik M, Kudo H, Toivonen P, Rozov S, Chen YC, Panula P: The histaminergic system regulates wakefulness and orexin/hypocretin neuron development via histamine receptor $\mathrm{H} 1$ in zebrafish. FASEB J 2011, 25(12):4338-4347.

9. Ishizuka T, Yamatodani A: Integrative role of the histaminergic system in feeding and taste perception. Front Syst Neurosci 2012, 6:44.

10. Benetti F, da Silveira CK, da Silva WC, Cammarota M, Izquierdo I: Histamine reverses a memory deficit induced in rats by early postnatal maternal deprivation. Neurobiol Learn Mem 2012, 97(1):54-58.

11. Ash AS, Schild HO: Receptors mediating some actions of histamine. Br J Pharmacol Chemother 1966, 27(2):427-439.

12. Nijmeijer $\mathrm{S}$, Leurs $\mathrm{R}$, Vischer HF: Constitutive activity of the histamine $\mathrm{H}(1)$ receptor. Methods Enzymol 2010, 484:127-147.

13. Threlfell S, Exley R, Cragg SJ, Greenfield SA: Constitutive histamine $\mathrm{H} 2$ receptor activity regulates serotonin release in the substantia nigra. J Neurochem 2008, 107(3):745-755.

14. Bhowmik M, Khanam R, Vohora D: Histamine $\mathrm{H} 3$ receptor antagonists in relation to epilepsy and neurodegeneration: a systemic consideration of recent progress and perspectives. Br J Pharmacol 2012, 167(7):1398-1414.

15. Schneider EH, Schnell D, Strasser A, Dove S, Seifert R: Impact of the DRY motif and the missing "ionic lock" on constitutive activity and G-protein coupling of the human histamine H4 receptor. J Pharmacol Exp Ther 2010, 333(2):382-392.

16. Seifert R, Wenzel-Seifert K: Constitutive activity of G-protein-coupled receptors: cause of disease and common property of wild-type receptors. Naunyn Schmiedebergs Arch Pharmacol 2002, 366(5):381-416.

17. Tao YX: Constitutive activation of $G$ protein-coupled receptors and diseases: insights into mechanisms of activation and therapeutics. Pharmacol Ther 2008, 120(2):129-148.

18. Bond RA, ljzerman AP: Recent developments in constitutive receptor activity and inverse agonism, and their potential for GPCR drug discovery. Trends Pharmacol Sci 2006, 27(2):92-96

19. Overington JP, Al-Lazikani B, Hopkins AL: How many drug targets are there? Nat Rev Drug Discov 2006, 5(12):993-996.

20. Hill SJ, Young JM: Evidence for the presence of histamine $\mathrm{H} 1$-receptors in guinea-pig brain [proceedings]. Br J Pharmacol 1978, 63(2):394P.

21. Chang RS, Tran VT, Snyder SH: Characteristics of histamine H1-receptors in peripheral tissues labeled with [3H]mepyramine. J Pharmacol Exp Ther 1979, 209(3):437-442.

22. Shimamura $T$, Shiroishi $M$, Weyand $S$, Tsujimoto $H$, Winter $G$, Katritch $V$, Abagyan R, Cherezov V, Liu W, Han GW, Kobayashi T, Stevens RC, Iwata S: Structure of the human histamine $\mathrm{H} 1$ receptor complex with doxepin. Nature 2011, 475(7354):65-70.

23. Smit MJ, Hoffmann M, Timmerman H, Leurs R: Molecular properties and signalling pathways of the histamine $\mathrm{H} 1$ receptor. Clin Exp Allergy 1999, 29(Suppl 3):19-28.

24. Masuoka T, Kamei $\mathrm{C}$ : Role of hippocampal $\mathrm{H} 1$ receptors in radial maze performance and hippocampal theta activity in rats. Brain Res Bull 2007, 73(4-6):231-237.

25. Huang ZL, Mochizuki T, Qu WM, Hong ZY, Watanabe T, Urade Y, Hayaishi O: Altered sleep-wake characteristics and lack of arousal response to $\mathrm{H} 3$ receptor antagonist in histamine $\mathrm{H} 1$ receptor knockout mice. Proc Natl Acad Sci U S A 2006, 103(12):4687-4692.

26. Lundius EG, Sanchez-Alavez M, Ghochani Y, Klaus J, Tabarean IV: Histamine influences body temperature by acting at $\mathrm{H} 1$ and $\mathrm{H} 3$ receptors on distinct populations of preoptic neurons. J Neurosci 2010, 30(12):4369-4381.

27. Mobarakeh Jl, Sakurada S, Katsuyama S, Kutsuwa M, Kuramasu A, Lin ZY, Watanabe T, Hashimoto $Y$, Yanai $\mathrm{K}$ : Role of histamine $\mathrm{H}(1)$ receptor in pain perception: a study of the receptor gene knockout mice. Eur J Pharmacol 2000, 391(1-2):81-89.

28. Black JW, Duncan WA, Durant CJ, Ganellin CR, Parsons EM: Definition and antagonism of histamine H 2 -receptors. Nature 1972, 236(5347):385-390.

29. Hegstrand LR, Kanof PD, Greengard P: Histamine-sensitive adenylate cyclase in mammalian brain. Nature 1976, 260(5547):163-165.

30. Dai H, Kaneko K, Kato H, Fujii S, Jing Y, Xu A, Sakurai E, Kato M, Okamura N, Kuramasu A, Yanai K: Selective cognitive dysfunction in mice lacking histamine $\mathrm{H} 1$ and $\mathrm{H} 2$ receptors. Neurosci Res 2007, 57(2):306-313.

31. Tabarean IV, Sanchez-Alavez M, Sethi J: Mechanism of $\mathrm{H}_{2}$ histamine receptor dependent modulation of body temperature and neuronal activity in the medial preoptic nucleus. Neuropharmacology 2012, 63(2):171-180
32. Alonso N, Fernandez N, Notcovich C, Monczor F, Simaan M, Baldi A, Gutkind JS, Davio C, Shayo C: Cross-desensitization and cointernalization of $\mathrm{H} 1$ and $\mathrm{H} 2$ histamine receptors reveal new insights into histamine signal integration. Mol Pharmacol 2013, 83(5):1087-1098.

33. Saligrama N, Noubade R, Case LK, del Rio R, Teuscher C: Combinatorial roles for histamine $\mathrm{H} 1-\mathrm{H} 2$ and $\mathrm{H} 3-\mathrm{H} 4$ receptors in autoimmune inflammatory disease of the central nervous system. Eur J Immunol 2012, 42(6):1536-1546.

34. Cangioli I, Baldi E, Mannaioni PF, Bucherelli C, Blandina P, Passani MB: Activation of histaminergic $\mathrm{H} 3$ receptors in the rat basolateral amygdala improves expression of fear memory and enhances acetylcholine release. Eur J Neurosci 2002, 16(3):521-528.

35. Gemkow MJ, Davenport AJ, Harich S, Ellenbroek BA, Cesura A, Hallett D: The histamine $\mathrm{H} 3$ receptor as a therapeutic drug target for CNS disorders. Drug Discov Today 2009, 14(9-10):509-515.

36. Bakker RA, Timmerman H, Leurs R: Histamine receptors: specific ligands, receptor biochemistry, and signal transduction. Clin Allergy Immunol 2002, 17:27-64.

37. Bongers G, Sallmen T, Passani MB, Mariottini C, Wendelin D, Lozada A Marle A, Navis M, Blandina P, Bakker RA, Panula P, Leurs R: The Akt/GSK-3beta axis as a new signaling pathway of the histamine $\mathrm{H}(3)$ receptor. J Neurochem 2007, 103(1):248-258.

38. Mariottini C, Scartabelli T, Bongers G, Arrigucci S, Nosi D, Leurs $R$, Chiarugi $A$ Blandina P, Pellegrini-Giampietro DE, Passani MB: Activation of the histaminergic $\mathrm{H} 3$ receptor induces phosphorylation of the Akt/GSK-3 beta pathway in cultured cortical neurons and protects against neurotoxic insults. J Neurochem 2009, 110(5):1469-1478.

39. Gomez-Ramirez J, Ortiz J, Blanco I: Presynaptic H3 autoreceptors modulate histamine synthesis through cAMP pathway. Mol Pharmacol 2002, 61(1):239-245.

40. Yamasaki T, Tamai I, Matsumura $\mathrm{Y}$ : Activation of histamine $\mathrm{H} 3$ receptors inhibits renal noradrenergic neurotransmission in anesthetized dogs. Am J Physiol Regul Integr Comp Physiol 2001, 280(5):R1450-R1456.

41. Gondard E, Anaclet C, Akaoka H, Guo RX, Zhang M, Buda C, Franco P, Kotani H, Lin JS: Enhanced histaminergic neurotransmission and sleep-wake alterations, a study in histamine $\mathrm{H} 3$-receptor knock-out mice. Neuropsychopharmacology 2013, 38(6):1015-1031.

42. Nakamura T, Itadani H, Hidaka Y, Ohta M, Tanaka K: Molecular cloning and characterization of a new human histamine receptor, HH4R. Biochem Biophys Res Commun 2000, 279(2):615-620.

43. Zampeli $\mathrm{E}$, Tiligada $\mathrm{E}$ : The role of histamine $\mathrm{H} 4$ receptor in immune and inflammatory disorders. Br J Pharmacol 2009, 157(1):24-33.

44. Moya-Garcia AA, Rodriguez CE, Morilla I, Sanchez-Jimenez F, Ranea JA The function of histamine receptor H4R in the brain revealed by interaction partners. Front Biosci (Schol Ed) 2011, 3:1058-1066.

45. Simon $T$, Laszlo V, Lang $O$, Buzas $E$, Falus $A$ : Histamine regulates relevant murine dendritic cell functions via H4 receptor. Front Biosci (Elite Ed) 2011, 3:1414-1424.

46. Mommert S, Gschwandtner M, Koether B, Gutzmer R, Werfel T: Human memory Th17 cells express a functional histamine $\mathrm{H} 4$ receptor. Am J Pathol 2012, 180(1):177-185.

47. Karlstedt K, Jin C, Panula P: Expression of histamine receptor Hrh3 and Hrh4 in rat brain endothelial cells. Br J Pharmacol 2013, 170(1):58-66.

48. Strakhova MI, Nikkel AL, Manelli AM, Hsieh GC, Esbenshade TA, Brioni JD, Bitner RS: Localization of histamine $\mathrm{H} 4$ receptors in the central nervous system of human and rat. Brain Res 2009, 1250:41-48.

49. Naddafi F, Mirshafiey A: The neglected role of histamine in Alzheimer's disease. Am J Alzheimers Dis Other Demen 2013, 28(4):327-336.

50. Brown JW, Whitehead CA, Basso AM, Rueter LE, Zhang M: Preclinical evaluation of non-imidazole histamine $\mathrm{H}(3)$ receptor antagonists in comparison to atypical antipsychotics for the treatment of cognitive deficits associated with schizophrenia. Int J Neuropsychopharmacol 2013, 16(4):889-904

51. Iwabuchi K, Ito C, Tashiro M, Kato M, Kano M, Itoh M, Iwata R, Matsuoka H, Sato $M$, Yanai K: Histamine $\mathrm{H} 1$ receptors in schizophrenic patients measured by positron emission tomography. Eur Neuropsychopharmacol 2005, 15(2):185-191.

52. Nishino S, Sakurai E, Nevsimalova S, Yoshida Y, Watanabe T, Yanai K, Mignot E: Decreased CSF histamine in narcolepsy with and without low CSF hypocretin-1 in comparison to healthy controls. Sleep 2009 32(2):175-180 
53. Rojas-Zamorano JA, Esqueda-Leon E, Jimenez-Anguiano A, Cintra-McGlone L, Mendoza Melendez MA, Velazquez Moctezuma J: The $\mathrm{H} 1$ histamine receptor blocker, chlorpheniramine, completely prevents the increase in REM sleep induced by immobilization stress in rats. Pharmacol Biochem Behav 2009, 91(3):291-294.

54. Bezprozvanny l: The rise and fall of Dimebon. Drug News Perspect 2010, 23(8):518-523.

55. Lankford A, Rogowski $R$, Essink $B$, Ludington $E$, Heith Durrence $H$, Roth $T$ : Efficacy and safety of doxepin $6 \mathrm{mg}$ in a four-week outpatient trial of elderly adults with chronic primary insomnia. Sleep Med 2012 13(2):133-138.

56. Rios Romenets S, Creti L, Fichten C, Bailes S, Libman E, Pelletier A, Postuma RB: Doxepin and cognitive behavioural therapy for insomnia in patients with Parkinson's disease-a randomized study. Parkinsonism Relat Disord 2013, 19(7):670-675.

57. Linday LA, Tsiouris JA, Cohen IL, Shindledecker R, DeCresce R: Famotidine treatment of children with autistic spectrum disorders: pilot research using single subject research design. J Neural Transm 2001 108(5):593-611.

58. Deutsch SI, Rosse RB, Kendrick KA, Fay-McCarthy M, Collins JP, Wyatt RJ: Famotidine adjunctive pharmacotherapy for schizophrenia: preliminary data. Clin Neuropharmacol 1993, 16(6):518-524.

59. Meskanen K, Ekelund H, Laitinen J, Neuvonen PJ, Haukka J, Panula P, Ekelund J: A randomized clinical trial of histamine 2 receptor antagonism in treatment-resistant Schizophrenia. J Clin Psychopharmacol 2013, 33(4):472-478.

60. Nathan PJ, Boardley R, Scott N, Berges A, Maruff P, Sivananthan T, Upton N Lowy MT, Nestor PJ, Lai R: The safety, tolerability, pharmacokinetics and cognitive effects of GSK239512, a selective histamine $\mathrm{H}_{3}$ receptor antagonist in patients with mild to moderate Alzheimer's disease: a preliminary investigation. Curr Alzheimer Res 2013, 10(3):240-251.

61. Haig GM, Pritchett Y, Meier A, Othman AA, Hall C, Gault LM, Lenz RA: A randomized study of $\mathrm{H} 3$ antagonist $A B T-288$ in mild-to-moderate Alzheimer's dementia. J Alzheimers Dis 2014, 42(3):959-971.

62. Haig GM, Bain E, Robieson W, Othman AA, Baker J, Lenz RA: A randomized trial of the efficacy and safety of the $\mathrm{H} 3$ antagonist ABT-288 in cognitive impairment associated with Schizophrenia. Schizophr Bull 2014, 40(6):1433-1442.

63. Galici R, Boggs JD, Aluisio L, Fraser IC, Bonaventure P, Lord B, Lovenberg TW: JNJ-10181457, a selective non-imidazole histamine $\mathrm{H}(3)$ receptor antagonist, normalizes acetylcholine neurotransmission and has efficacy in translational rat models of cognition. Neuropharmacology 2009, 56(8):1131-1137.

64. Lin JS, Dauvilliers $Y$, Arnulf I, Bastuji H, Anaclet $C$, Parmentier R, Kocher $L$, Yanagisawa M, Lehert P, Ligneau X, Perrin D, Robert P, Roux M, Lecomte JM, Schwartz JC: An inverse agonist of the histamine $\mathrm{H}(3)$ receptor improves wakefulness in narcolepsy: studies in orexin-/- mice and patients. Neurobiol Dis 2008, 30(1):74-83.

65. Weisler RH, Pandina GJ, Daly EJ, Cooper K, Gassmann-Mayer C, Investigators AS: Randomized clinical study of a histamine $\mathrm{H} 3$ receptor antagonist for the treatment of adults with attention-deficit hyperactivity disorder. CNS Drugs 2012, 26(5):421-434.

66. Poyurovsky M, Fuchs C, Pashinian A, Levi A, Weizman R, Weizman A: Reducing antipsychotic-induced weight gain in schizophrenia: a double-blind placebo-controlled study of reboxetine-betahistine combination. Psychopharmacology (Berl) 2013, 226(3):615-622.

67. Galici R, Rezvani AH, Aluisio L, Lord B, Levin ED, Fraser I, Boggs J, Welty N, Shoblock JR, Motley ST, Letavic MA, Carruthers NI, Dugovic C, Lovenberg TW, Bonaventure P: JNJ-39220675, a novel selective histamine $\mathrm{H} 3$ receptor antagonist, reduces the abuse-related effects of alcohol in rats. Psychopharmacology (Berl) 2011, 214(4):829-841.

68. Browman KE, Komater VA, Curzon P, Rueter LE, Hancock AA, Decker MW Fox GB: Enhancement of prepulse inhibition of startle in mice by the $\mathrm{H} 3$ receptor antagonists thioperamide and ciproxifan. Behav Brain Res 2004, 153(1):69-76.

69. Nowak P, Noras L, Jochem J, Szkilnik R, Brus H, Körossy E, Drab J, Kostrzewa RM, Brus R: Histaminergic activity in a rodent model of Parkinson's disease. Neurotox Res 2009, 15(3):246-251.

70. Medhurst SJ, Collins SD, Billinton A, Bingham S, Dalziel RG, Brass A, Roberts JC, Medhurst AD, Chessell IP: Novel histamine $\mathrm{H} 3$ receptor antagonists GSK189254 and GSK334429 are efficacious in surgically-induced and virally-induced rat models of neuropathic pain. Pain 2008, 138(1):61-69.

71. Hsieh GC, Honore P, Pai M, Wensink EJ, Chandran P, Salyers AK, Wetter JM, Zhao C, Liu H, Decker MW, Esbenshade TA, Cowart MD, Brioni JD: Antinociceptive effects of histamine $\mathrm{H} 3$ receptor antagonist in the preclinical models of pain in rats and the involvement of central noradrenergic systems. Brain Res 2010, 1354:74-84.

72. Griebel G, Pichat P, Pruniaux MP, Beeské S, Lopez-Grancha M, Genet E, Terranova JP, Castro A, Sánchez JA, Black M, Varty GB, Weiner I, Arad M, Barak S, De Levie A, Guillot E: SAR1 10894, a potent histamine $\mathrm{H}_{3}$-receptor antagonist, displays procognitive effects in rodents. Pharmacol Biochem Behav 2012, 102(2):203-214.

73. Bardgett ME, Davis NN, Schultheis PJ, Griffith MS: Ciproxifan, an H3 receptor antagonist, alleviates hyperactivity and cognitive deficits in the APP Tg2576 mouse model of Alzheimer's disease. Neurobiol Learn Mem 2011, 95(1):64-72.

74. Coruzzi G, Pozzoli C, Adami M, Grandi D, Guido N, Smits R, de Esch I, Leurs $\mathrm{R}$ : Strain-dependent effects of the histamine $\mathrm{H}_{4}$ receptor antagonist JNJ7777120 in a murine model of acute skin inflammation. Exp Dermatol 2012, 21(1):32-37.

75. Hsieh GC, Chandran P, Salyers AK, Pai M, Zhu CZ, Wensink EJ, Witte DG, Miller TR, Mikusa JP, Baker SJ, Wetter JM, Marsh KC, Hancock AA, Cowart MD, Esbenshade TA, Brioni JD, Honore P: H4 receptor antagonism exhibits anti-nociceptive effects in inflammatory and neuropathic pain models in rats. Pharmacol Biochem Behav 2010, 95(1):41-50.

76. Liu WL: Histamine $\mathrm{H} 4$ receptor antagonists for the treatment of inflammatory disorders. Drug Discov Today 2014, 19(8):1222-1225.

77. Thies W, Bleiler L: Association As: 2013 Alzheimer's disease facts and figures. Alzheimers Dement 2013, 9(2):208-245.

78. Shan L, Bossers K, Unmehopa U, Bao AM, Swaab DF: Alterations in the histaminergic system in Alzheimer's disease: a postmortem study. Neurobiol Aging 2012, 33(11):2585-2598.

79. Kim SH, Cairns N, Fountoulakisc M, Lubec G: Decreased brain histamine-releasing factor protein in patients with Down syndrome and Alzheimer's disease. Neurosci Lett 2001, 300(1):41-44.

80. Doody RS, Gavrilova SI, Sano M, Thomas RG, Aisen PS, Bachurin SO, Seely L, Hung $D$, investigators $d$ : Effect of dimebon on cognition, activities of daily living, behaviour, and global function in patients with mild-to-moderate Alzheimer's disease: a randomised, double-blind, placebo-controlled study. Lancet 2008, 372(9634):207-215.

81. Grove RA, Harrington CM, Mahler A, Beresford I, Maruff P, Lowy MT, Nicholls AP, Boardley RL, Berges AC, Nathan PJ, Horrigan JP: A randomized, double-blind, placebo-controlled, 16-week study of the H3 receptor antagonist, GSK239512 as a monotherapy in subjects with mild-to-moderate Alzheimer's disease. Curr Alzheimer Res 2014, 11(1):47-58.

82. Vanni-Mercier G, Sakai K, Jouvet M: [Specific neurons for wakefulness in the posterior hypothalamus in the cat]. C R Acad Sci III 1984, 298(7):195-200.

83. Parmentier R, Ohtsu H, Djebbara-Hannas Z, Valatx JL, Watanabe T, Lin JS. Anatomical, physiological, and pharmacological characteristics of histidine decarboxylase knock-out mice: evidence for the role of brain histamine in behavioral and sleep-wake control. J Neurosci 2002, 22(17):7695-7711.

84. Kanbayashi T, Kodama T, Kondo H, Satoh S, Inoue Y, Chiba S, Shimizu T, Nishino S: CSF histamine contents in narcolepsy, idiopathic hypersomnia and obstructive sleep apnea syndrome. Sleep 2009, 32(2):181-187.

85. Unno K, Ozaki T, Mohammad S, Tsuno S, Ikeda-Sagara M, Honda K, Ikeda M: First and second generation $\mathrm{H}_{1}$ histamine receptor antagonists produce different sleep-inducing profiles in rats. Eur J Pharmacol 2012, 683(1-3):179-185.

86. Inocente C, Arnulf I, Bastuji H, Thibault-Stoll A, Raoux A, Reimão R, Lin JS, Franco P: Pitolisant, an inverse agonist of the histamine $\mathrm{H} 3$ receptor: an alternative stimulant for narcolepsy-cataplexy in teenagers with refractory sleepiness. Clin Neuropharmacol 2012, 35(2):55-60.

87. Jucaite A, Takano A, Boström E, Jostell KG, Stenkrona P, Halldin C, Segerdahl M, Nyberg S: AZD5213: a novel histamine $\mathrm{H} 3$ receptor antagonist permitting high daytime and low nocturnal $\mathrm{H} 3$ receptor occupancy, a PET study in human subjects. Int J Neuropsychopharmacol 2013, 16(6):1231-1239.

88. Jouan L, Girard SL, Dobrzeniecka S, Ambalavanan A, Krebs MO, Joober R, Gauthier J, Dion PA, Rouleau GA: Investigation of rare variants in LRP1, 
KPNA1, ALS2CL and ZNF480 genes in schizophrenia patients reflects genetic heterogeneity of the disease. Behav Brain Funct 2013, 9:9.

89. Seeman P: Dopamine D2 receptors as treatment targets in schizophrenia. Clin Schizophr Relat Psychoses 2010, 4(1):56-73.

90. Bishara D: Once-monthly paliperidone injection for the treatment of schizophrenia. Neuropsychiatr Dis Treat 2010, 6:561-572.

91. Jin $\mathrm{CY}$, Anichtchik O, Panula P: Altered histamine $\mathrm{H} 3$ receptor radioligand binding in post-mortem brain samples from subjects with psychiatric diseases. Br J Pharmacol 2009, 157(1):118-129.

92. Wei Z, Wang L, Yu T, Wang Y, Sun L, Wang T, Huo R, Li Y, Wu X, Qin S, Xu Y, Feng G, He L, Xing Q: Histamine H4 receptor polymorphism: a potential predictor of risperidone efficacy. J Clin Psychopharmacol 2013, 33(2):221-225

93. Rosse RB, Kendrick K, Fay-McCarthy M, Prell GD, Rosenberg P, Tsui LC, Wyatt RJ, Deutsch SI: An open-label study of the therapeutic efficacy of high-dose famotidine adjuvant pharmacotherapy in schizophrenia: preliminary evidence for treatment efficacy. Clin Neuropharmacol 1996 19(4):341-348

94. Mahmood D, Khanam R, Pillai KK, Akhtar M: Reversal of oxidative stress by histamine $\mathrm{H}_{3}$ receptor-ligands in experimental models of schizophrenia. Arzneimittelforschung 2012, 62(5):222-229.

95. Wong MM, Chen EY, Lui SS, Tso S: Medication adherence and subjective weight perception in patients with first-episode psychotic disorder. Clin Schizophr Relat Psychoses 2011, 5(3):135-141.

96. Xia Y, Ma D, Hu J, Tang C, Wu Z, Liu L, Xin F: Effect of metabotropic glutamate receptor 3 genotype on $\mathrm{N}$-acetylaspartate levels and neurocognition in non-smoking, active alcoholics. Behav Brain Funct 2012, $8: 42$.

97. Wang TY, Lee SY, Chen SL, Chang YH, Chen SH, Chu CH, Huang SY, Tzeng NS, Wang CL, Lee IH, Yeh TL, Yang YK, Lu RB: Interaction between serotonin transporter and serotonin receptor $1 \mathrm{~B}$ genes polymorphisms may be associated with antisocial alcoholism. Behav Brain Funct 2012, 8:18.

98. Guindalini C, Laranjeira R, Collier D, Messas G, Vallada H, Breen G: Dopamine-beta hydroxylase polymorphism and cocaine addiction. Behav Brain Funct 2008, 4:1.

99. Oroszi G, Enoch MA, Chun J, Virkkunen M, Goldman D: Thr105lle, a functional polymorphism of histamine $\mathrm{N}$-methyltransferase, is associated with alcoholism in two independent populations. Alcohol Clin Exp Res 2005, 29(3):303-309.

100. Nuutinen S, Panula P: Histamine in neurotransmission and brain diseases. Adv Exp Med Biol 2010, 709:95-107.

101. Coelho MH, Silva IJ, Azevedo MS, Manso CF: Decrease in blood histamine in drug-treated parkinsonian patients. Mol Chem Neuropathol 1991, 14(2):77-85.

102. Anichtchik OV, Rinne JO, Kalimo H, Panula P: An altered histaminergic innervation of the substantia nigra in Parkinson's disease. Exp Neurol 2000, 163(1):20-30.

103. Rinne JO, Anichtchik OV, Eriksson KS, Kaslin J, Tuomisto L, Kalimo H, Röyttä M, Panula P: Increased brain histamine levels in Parkinson's disease but not in multiple system atrophy. J Neurochem 2002, 81(5):954-960

104. Shan L, Bossers K, Luchetti S, Balesar R, Lethbridge N, Chazot PL, Bao AM, Swaab DF: Alterations in the histaminergic system in the substantia nigra and striatum of Parkinson's patients: a postmortem study. Neurobiol Aging 2012, 33(7):1488. e1481-1413.

105. McCarthy M: Autism diagnoses in the US rise by $30 \%, C D C$ reports. BMJ 2014, 348:92520.

106. Linday LA: Oral famotidine: a potential treatment for children with autism. Med Hypotheses 1997, 48(5):381-386.

107. Neville BG, Bentovim A, Clayton BE, Shepherd J: Histidinaemia. Study of relation between clinical and biological findings in 7 subjects. Arch Dis Child 1972, 47(252):190-200.

108. Kotsopoulos S, Kutty KM: Histidinemia and infantile autism. J Autism Dev Disord 1979, 9(1):55-60.

109. Launay JM, Ferrari P, Haimart M, Bursztejn C, Tabuteau F, Braconnier A, Pasques-Bondoux D, Luong C, Dreux C: Serotonin metabolism and other biochemical parameters in infantile autism. A controlled study of 22 autistic children. Neuropsychobiology 1988, 20(1):1-11.

110. Rossi PG, Posar A, Parmeggiani A, Pipitone E, D'Agata M: Niaprazine in the treatment of autistic disorder. J Child Neurol 1999, 14(8):547-550
111. Rosales-Reynoso MA, Ochoa-Hernández AB, Aguilar-Lemarroy A, Jave-Suárez LF, Troyo-Sanromán R, Barros-Núñez P: Gene expression profiling identifies WNT7A as a possible candidate gene for decreased cancer risk in fragile $X$ syndrome patients. Arch Med Res 2010, 41(2):110-118. e112.

112. Ming X, Stein TP, Barnes V, Rhodes N, Guo L: Metabolic perturbance in autism spectrum disorders: a metabolomics study. J Proteome Res 2012, 11(12):5856-5862.

113. Naushad SM, Jain JM, Prasad CK, Naik U, Akella RR: Autistic children exhibit distinct plasma amino acid profile. Indian J Biochem Biophys 2013, 50(5):474-478.

114. Fernandez TV, Sanders SJ, Yurkiewicz IR, Ercan-Sencicek AG, Kim YS, Fishman DO, Raubeson MJ, Song Y, Yasuno K, Ho WS, Bilguvar K, Glessner J, Chu SH, Leckman JF, King RA, Gilbert DL, Heiman GA, Tischfield JA, Hoekstra PJ, Devlin B, Hakonarson H, Mane SM, Günel M, State MW: Rare copy number variants in tourette syndrome disrupt genes in histaminergic pathways and overlap with autism. Biol Psychiatry 2012, 71(5):392-402.

115. Bambini-Junior V, Baronio D, MacKenzie J, Zanatta G, Dos Santos Riesgo R, Gottfried C: Prenatal exposure to valproate in animals and autism. In Comprehensive Guide to Autism, Volume Volume 3. 1st edition. Edited by Patel VB, Preedy VR, Martin CR. New York: Springer; 2014:1779-1793.

\section{doi:10.1186/s12991-014-0034-y}

Cite this article as: Baronio et al:: Histaminergic system in brain disorders: lessons from the translational approach and future perspectives. Annals of General Psychiatry 2014 13:34.

\section{Submit your next manuscript to BioMed Central and take full advantage of:}

- Convenient online submission

- Thorough peer review

- No space constraints or color figure charges

- Immediate publication on acceptance

- Inclusion in PubMed, CAS, Scopus and Google Scholar

- Research which is freely available for redistribution

Submit your manuscript at www.biomedcentral.com/submit
Ciomed Central 